\title{
The Effect of Australia's Declining Fertility Rate 1978-2016
}

\author{
Ejiro U. Osiobe \\ The Department of Economics, Applied Statistics, and International Business \\ New Mexico State University \\ MSC 3CQ P. O. BOX 30001 \\ Las Cruces, NM 88003-8001, USA \\ E-mail: euosiobe@nmsu.edu or jiji@aneosiobe.ngo
}

Received: Sept. 28, 2019 Accepted: Oct. 17, 2019 Online published: Oct. 27, 2019

doi:10.5296/ijhrs.v9i4.15717ＵRL: https://doi.org/10.5296/ijhrs.v9i4.15717

\begin{abstract}
The paper presents an analytic framework that describes how the declining fertility rate of Australia between 1978 - 2016 has affected its economy. Issues related to population have long been the subject of debate in the industrialized countries like the United States and European nations following the shift in their population structure. The awareness of the declining fertility rate in Australia remains a concern to the Australian government as the new trend will reshape the country's demographic pattern. This paper seeks to examine the fertility rate of Australia and how it has affected GDP per capita. The study uses the simple ordinary least squares (OLS) methodology to analyze this effect. Our result showed an inverse relationship between fertility rate in Australia and per capita income.
\end{abstract}

Keywords: Australia, fertility rate, declining, GDP per capita

\section{Introduction}

Australia is the world's smallest continent and the 6th largest country. Over the past decades, Australia's fertility rate has been declining. Becker et al. (1990) examined the maximizing utility of children with constrained resources. This study argues that the fertility rate has a direct effect on per capita income. 


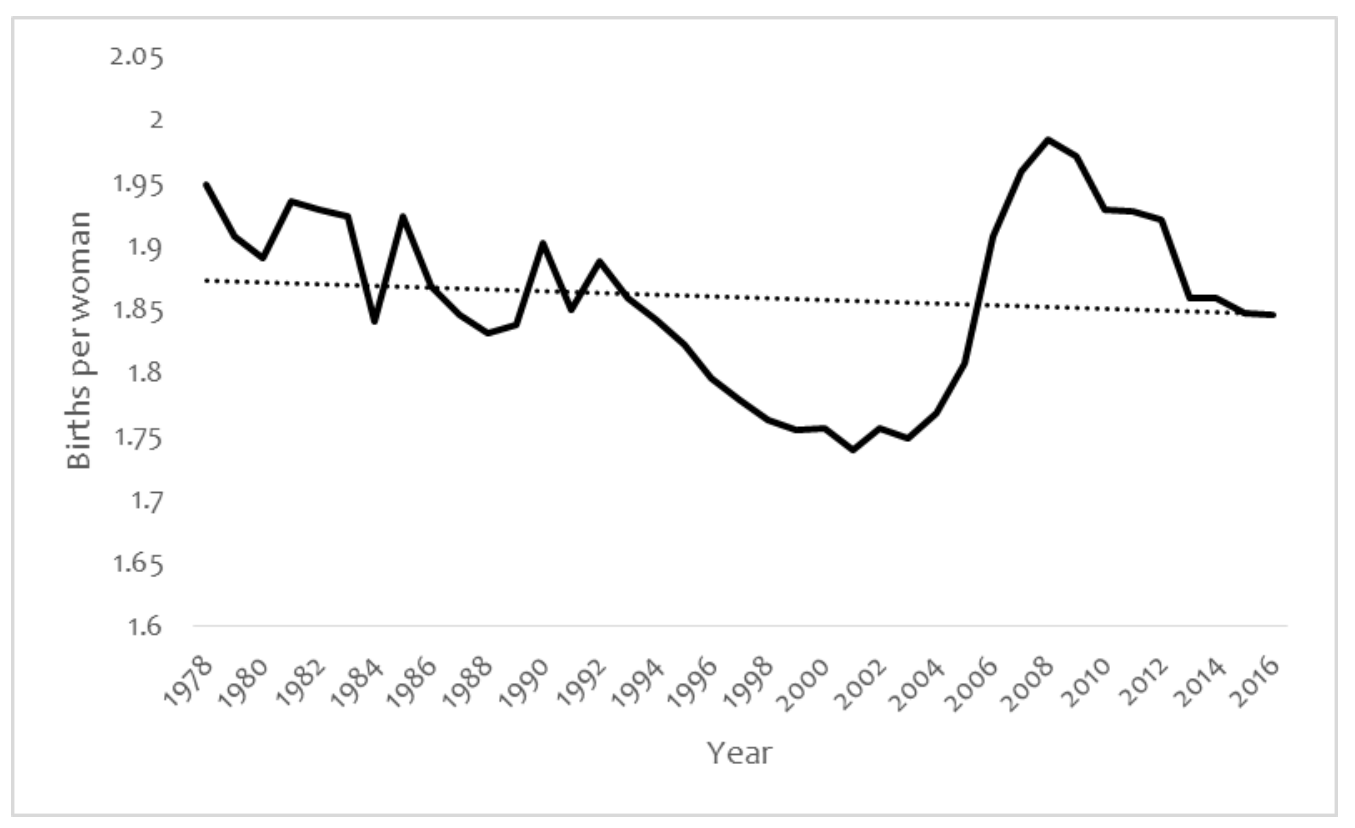

Figure 1. The Trend of Australia's Fertility Rate 1978 - 2016

Since the last century, developed nations' have seen more than a 50\% decline in their fertility rate. This phenomenon is interesting as the nation of Australia saw a sharp decline between 1992 and early 2000. The history of the declining fertility rate in Australia is unique because the country never faced many of the socio-economic adjustment problems that molded the industrial ear in North America and Europe.

\section{Literature Review}

Becker (et al. (1960, 1990, \& 1992)) overall, views the relationship between income level and the cost of raising a child while maximizing utility. His theory of fertility choice argued that an economic model(s), treats children as analogous to consumer durable goods such as cars and houses, and this could explain the reason(s) why some people have children and others do not.

He assumes societies with limited human capital choose larger families and invest little in each member while those with abundant, do the opposite. Thus, this will lead to a stable, steady-state. In his conclusion, he states that societies can maximize their capital across generations by significantly investing in each child, and in the long-run, the accumulation of physical capital will lead to economic growth and development. Becker's paper on fertility and the economy also related the demand for children to parental income and the cost of raising children, especially to the value of the time spent on childcare and public policies that change the price of children.

Jones (1971) analyzed the history of Australia and New Zealand's fertility decline and compared it to that of Europe. His study looked at the urban-rural division of each state in Australia, excluding Tasmania. The paper addressed the urban-rural birth registration concerns and adjusted for the difference over time. Jones (1971) finds in his analysis that 


\section{Macrothink}

International Journal of Human Resource Studies

ISSN 2162-3058 2019, Vol. 9, No. 4

there was a significant decline in the overall fertility and specifically in the fertility of married couples, dating back to the 1880 s. The paper concluded that marital fertility probably hit a plateau or declined rapidly in $1860-1880$, and that trend has become the new status quo.

\section{Data Source and Empirical Model}

The primary source of our data was the World Development Index and the Australian Bureau of Statistics. The paper used a time-series OLS estimation from $1978-2016$.

$$
\ln G D P_{p e r_{i}}=\beta_{0}+\beta_{1} \ln F R T_{i}+\beta_{2} \ln D R T_{i}+\beta_{3} \ln L E_{i}+\beta_{4} \ln P O P_{i}+\beta_{5} \ln F L F_{i}+\varepsilon_{i}
$$

where $\ln \ln P_{\text {per }}$ is GDP per capita (constant LCU); ${\ln G D P_{\text {per }}}_{i}$ is defined as the per capita constant, of the local currency of Australia; $\ln F R T_{i}$ is the fertility rate (births per woman). $\ln D R T_{i}$ is the age dependency ratio as a percentage of the working-age population in Australia. $\ln L E_{i}$ is the life expectancy at birth; $\ln P O P_{i}$ represents the total population of women as a percentage of Australia's total population; and $\ln F L F_{i}$ is defined as the total number of females in the labor force per thousand.

\subsection{Results}

\begin{tabular}{|c|c|c|}
\hline Variables & $\begin{array}{c}\text { Co-efficient } \\
\text { (t-stat) }\end{array}$ & VIF \\
\hline $\ln D R T_{i}$ & $\begin{array}{c}-0.0382 \\
(-0.1743)\end{array}$ & 1.69 \\
\hline $\ln F R T_{i}$ & $\begin{array}{c}-0.260 \\
(-2.0831) * * *\end{array}$ & 4.13 \\
\hline $\ln L E_{i}$ & $\begin{array}{c}6.058 \\
(27.919) * * * *\end{array}$ & 4.06 \\
\hline $\ln P O P_{i}$ & $\begin{array}{c}-11.472 \\
(-3.250) * * * *\end{array}$ & 2.06 \\
\hline $\ln F L F$ & $\begin{array}{c}-0.007 \\
(-0.7373)\end{array}$ & 1.69 \\
\hline Constant & $\begin{array}{l}29.670 \\
(2.013)\end{array}$ & \\
\hline$R$-Squared & 0.99 & \\
\hline Adj. R-Squared & 0.98 & \\
\hline$F$-statistic & 753.162 & \\
\hline$D W$-Test & 0.97 & \\
\hline$N$ & 39 & \\
\hline
\end{tabular}


$* * * * 99.9 \%$ Confidence

$* * * 99 \%$ Confidence

Our result(s) shows a $1 \%$ increase in $\ln F R T_{i}$ will lead to a $0.26 \%$-point decrease in $\ln G D P_{\text {per }}$ the relationship can be associated with the (likelihood) number of children born in a given time, which can also be linked to the quality of the child (education attainment), which translates to human capital, which is a significant factor of production. If $\ln F R T_{i}$ doesn't translate to a high Human Development Index (HDI) point in Australia, our stated result will not be too farfetched as supported by (Ardichvili, Zavyalova, \& Minina, 2012). A $1 \%$ increase in $\ln L E_{i}$ will lead to a $6.05 \%$-point increase in $\ln _{G D} P_{p e r}$ the relationship can be associated with the ideology that states, the more healthy people are in an economy, the higher the chances that the nation's real gross domestic product will increase. Hence, translating to an increase in the individual's per capita income as supported by (Bloom, Canning, \& Sevilla, 2004) and (Fogel, 1997). A 1\% increase in $\ln P O P_{i}$ will lead to an $11.47 \%$-point decrease in $\ln G D P_{p e r_{i}}$. If the birth rate (births per thousand) in Australia increases as a result of $\ln P O P_{i}$ increasing and the social cost of the economy's additional $c_{O 2}$ emission is accounted for ceteris paribus, thus the result holds to be true (Elshkaki, Voet, Holderbeke, \& Timmermans, 2004).

\section{Conclusion}

This study has assessed the trend and pattern of Australia's fertility rate and investigated the direct effect(s) of the explanatory variables on per capita income. The study uses the OLS technique and time-series data to test the factors that drive the upward fluctuation in Australia's GDP per capita. The results of this study show as $\ln F R T_{i}$ and $\ln P O P_{i}$ Increases, the $\ln _{G D} P_{p e r_{i}}$ decreases. On the other hand, as $\ln L E_{i}$ increases, $\ln G D P_{p e r}$ increases. The policy implication of the study supports the view that demographic planners will need to take a detailed account of fertility rates as it relates to per capita income. Investment in human and physical capital has the potential to increase the nation's GDP per capita, improve technology, and promote long term economic growth and development.

\section{References}

Ardichvili, A., Zavyalova, E., \& Minina, V. (2012). Human Capital Development: Comparative Analysis of BRICs. European Journal of Training and Development, 213-233. https://doi.org/10.1108/03090591211204724

Barro, R. J. (1991). Economic Growth in a Cross-Section of Countries. The quarterly Journal of Economics, 106(2), 407-443. https://doi.org/10.2307/2937943 
Basavarajappa, K. (1971). The Influence of Fluctuation in Economic Condition on Fertility and Marriage Rates, Australia 1920-21 to 1937-38 and 1946-47 to 1966-67. Journal of Population Studies, 39-53. https://doi.org/10.1080/00324728.1971.10405781

Becker, G. S. (1960). An Economic Analysis of Fertility. National Bureau of Economic Research, 209-240.

Becker, G. S. (1992). Fertility and the Economy. Journal of Population Economics, 185-201. https://doi.org/10.1007/BF00172092

Becker, G. S., Murphy, K. M., \& Tamura, R. (1990). Human Capital, Fertility, and Economic Growth. Journal of Political Economy. https://doi.org/10.1086/261723

Blackburn, K., \& Pietro, G. C. (2002). A Model of Longevity, Fertility, and Growth. Journal of Economic Dynamics and Control, 187-2004. https://doi.org/10.1016/S0165-1889(00)00022-1

Blacklow, P. (2006). Fertility Choices of Australian Couple. Discussion Paper 2006-07.

Bloom, E. D., Canning, D., \& Sevilla, J. (2004). The Effect of Health on Economic Growth: A Production Function Approach. World Development, 1-13. https://doi.org/10.1016/j.worlddev.2003.07.002

Chaudhry, D. M., \& Choudhry, K. N. (1985). The Fertility rate in Canada, 1950-1976: A Socio-Econometric Analysis. Canadian Studies in Population, 1-30. https://doi.org/10.25336/P6J01B

De Santis, G., Drefahl, S., \& Vignoli, D. (2014). A period Total Fertility Rate with Covariates for Short-Panel Data. Population, 419-432.

Diebolt, C., \& Doliger, C. (2005). Becker Vs. Easterlin Education, Fertility, and Growth in France after World War II. Association Francaise De Cliometrie (AFC) Working Paper.

Doepke, M. (2015). Gary Becker on the Quantity and Quality of Children. Journal of Demographic Economics, 59-66. https://doi.org/10.1017/dem.2014.8

Dzhumashev, R., \& Tursunalieva, A. (2016). Keeping up with the Joneses and Fertility choice. Monash Business School of Economics (Discussion Paper).

Elshkaki, A., Voet, V.-d. E., Holderbeke, V. M., \& Timmermans, V. (2004). The environmental and economic consequences of the development of lead stocks in the Dutch economic system. Resources, Conservation, and Recycling, 133-154. https://doi.org/10.1016/j.resconrec.2004.02.008

Fogel, W. R. (1997). Chapter 9: New Findings on Secular Trends in Nutrition and Mortality: Some Implication for Population Theory. In Handbook of Population and Family Economics (pp. 433-481). Elsevier B.V. https://doi.org/10.1016/S1574-003X(97)80026-8

Fox, J., Klusener, S., \& Myrskyla, M. (2019). Is a Positive Relationship between Fertility and Economic Development Emerging at the Sub-National Regional Level? Theoretical 


\section{Macrothink}

International Journal of Human Resource Studies

ISSN 2162-3058 2019, Vol. 9, No. 4

Considerations and Evidence from Europe. European Journal of Population, 487-518. https://doi.org/10.1007/s10680-018-9485-1

Jones, E. F. (1971). Fertility Decline in Australia and New Zealand 1861 - 1936. Office of Population Research, 301-338. https://doi.org/10.2307/2733841

Murphy, G. S. (1990). Human Capital, Fertility, and Economic Growth. Journal of Political Economy, 98(3).

Peter Mcdonald, P., Kakim, C. H., \& Phillips. (2002). Fertility rates, women in the workforce, and economic health. Family Matters, 50-53.

Raganathan, S., Swain, R. B., \& Sumpter, D. J. (2015). The Demographic Transition and Economic Growth: A Dynamical System Model. https://doi.org/10.1057/palcomms.2015.33

Rosenzweig, R. M., \& Oded, S. (1997). Handbook of Population and Family Economics. Amsterdam: Elsevier BV.

Sommer, K. (2016). Fertility choice in a life cycle model with idiosyncratic uninsurable earnings risk. Journal of Monetary Economics, 27-38. https://doi.org/10.1016/j.jmoneco.2016.08.002

The Australian Bureau of Statistics. (2019). Retrieved from http://www.abs.gov.au/AUSSTATS/abs@.nsf/DetailsPage/6202.0Dec\%202016?OpenDocum ent

The World Development Index. (2019). Retrieved from http://data.worldbank.org/country/australia

\section{Copyright Disclaimer}

Copyright for this article is retained by the author(s), with first publication rights granted to the journal.

This is an open-access article distributed under the terms and conditions of the Creative Commons Attribution license (http://creativecommons.org/licenses/by/4.0/). 